\title{
Hereditary Slavery Shackles Mauritania
}

\author{
Shaul M. Gabbay ${ }^{1}$ \\ ${ }^{1} \mathrm{Ph}$. D., Global Research Institute, Denver, Colorado USA \\ Correspondence: Professor Shaul M. Gabbay, Global Research Institute, Denver, Colorado USA.
}

Received: August 12, 2020

Accepted: November 11, $2020 \quad$ Available online: November 24, 2020

doi:10.11114/ijsss.v9i1.5088

URL: https://doi.org/10.11114/ijsss.v9i1.5088

\begin{abstract}
This paper exposes the scourge of slavery that continues to thrive in the country of Mauritania in modern times. Though the practice is formally abolished and illegal, and the government continues to claim slavery has been eradicated, the truth lies elsewhere. 90,000 dark-skinned slaves, often referred to as Black Moors, continue to live deplorable lives in servitude to their lighter-skinned masters. The Mauritanian government is helping the scourge of slavery endure by denying its existence and providing it cover. Their task is made easier as the face of slavery changes and becomes hidden in the throes of modern commerce, making it more difficult for an outsider to differentiate between a low-income wage earner and a slave. Other situations are painfully identifiable, such as conducting human trafficking for purposes of prostitution. In all situations, women and children make up the vast majority of indentured servants. Due to a forced dearth of educational opportunity, slaves are often illiterate and therefore largely unable to emancipate themselves without outside help. Deeply entrenched belief systems, practices, and governmental and societal structures that exist in Mauritania secure an environment that allows slavery to continue to thrive. In addition to the Mauritanian government, businesses, educational facilities, NGO's, and members of society at every level must take decisive action to eradicate the practice and change the beliefs that hold it in place. Foreign governments and businesses hold great power in their willingness to engage with Mauritanian leaders. By withholding financial aid and business deals international players have the opportunity to hasten the eradication of slavery in Mauritania This paper examines the depth of the slavery problem and recommends multiple steps for its elimination.
\end{abstract}

Keywords: slavery, black Moors, poverty, Mauritania, trafficking

\section{Introduction}

The practice of slavery, a human exploitation once routinely practiced and accepted in nearly every society on earth, has slowly faded from social and legal acceptance over the past two centuries. Long practiced by colonizers and supported by religious doctrines and traditions, today, the practice is illegal in every nation individually as well as by international law, which defines slavery as "the status or condition of a person over whom any or all of the powers attaching to the right of ownership are exercised." (Marlin \& Mathewson, 2015).

Despite social repugnance and outright illegality, this illicit practice exists in every nation on earth even as it stealthily drops out of view. Today at least 40 million people $-71 \%$ of whom are women, and $25 \%$ children - continue to suffer some form of bondage. (Anti-Slavery International, 2020.)

In the country of Mauritania, located on Western African on the north Atlantic coast, human bondage is entrenched and concealed. (Minderoo Foundation, 2019.) The global slavery index rates Mauritania as having the 6th highest prevalence of modern slavery in the world, yet the government denies its existence, citing a few rare incidences as aberrations. Unfortunately, reality speaks otherwise as an estimated 90,000 Mauritanian citizens continue to be subjected to slavery in 2020 , or $2.4 \%$ of the total population. (Voice of America, 2018.)

When Mauritania formally abolished slavery in 1981, it was the last country in the world to do so. It would take another 26 years for its government to pass a law enforcing abolition. The government acted reluctantly and only in response to intense international pressure. Given their lackluster efforts to implement the new law, many believe the abolishment to be window-dressing, a guise to appear concerned without any serious intent to end the practice. The word 'practice' dulls the scope of the true depravity: this is slavery in the truest sense, in which slaves are forbidden from owning property, from having a last name, or of possessing legal custody of their own children. (The Atlantic, 2011.) This 'non-person' status leads to unspeakable horrors that such a status often merits, such as horrific working and living 
conditions, physical abuse of all kinds including rape, and a dearth of hope for a better life.

In the years following its formal abolishment, a mere handful of perpetrators were charged with slave ownership or trading, and in those rare instances the accused were charged with an offense as opposed to a crime. The underlying message to slave owners and traders indicated they need not take abolishment all that seriously. In 2007, Mauritania's government finally surrendered once again to overwhelming pressure both at home and internationally and criminalized slave ownership and slave trade. Finally, slave traders and owners would be fined and incarcerated, the estimated 500,000 slaves would win freedom in Mauritania. In the thirteen years since, the number of slaves has dropped significantly or gone into hiding. According to Human Rights Watch Report on Mauritania (2020), "Three special courts that prosecute slavery-related crimes have tried a handful of cases since their creation under a 2015 law. Of those, Mauritania investigated four cases, prosecuted one alleged trafficker, but did not convict any. Nine appeals cases remained pending at the anti-slavery court."

Despite international pressure and local activism, Mauritanian slavery is deeply entrenched and the road to freedom extends years into the future.

\section{Country Profile Bolsters Slavery}

Mauritania's geographic, demographic, and historical aspects have coalesced in a manner that fuels its practice of slavery and keeps it firmly established. Located in Western Africa bordering the North Atlantic Ocean, Mauritania sits between Senegal to the south and Western Sahara to the north. The land is brutally inhospitable, blanketed by the Saharan Desert. The entire country is barren and unforgiving, with only four tenths of one percent of its land mass considered arable. Not one body of water graces the entire country. The only fresh water source, the Senegal River, borders its southern edge and runs between Mauritania and its southern neighbor that shares a name with the river. The result has been ongoing conflict over the water that runs on as reliably as the river itself.

The Islamic Republic of Mauritania, one of a handful of uniformly Muslim countries in the world, suffers from extreme poverty with $40 \%$ of its population living below the poverty line. Food insecurity, fragile natural resources, high unemployment, and a significant lack of formal education and hamper efforts to secure human rights.

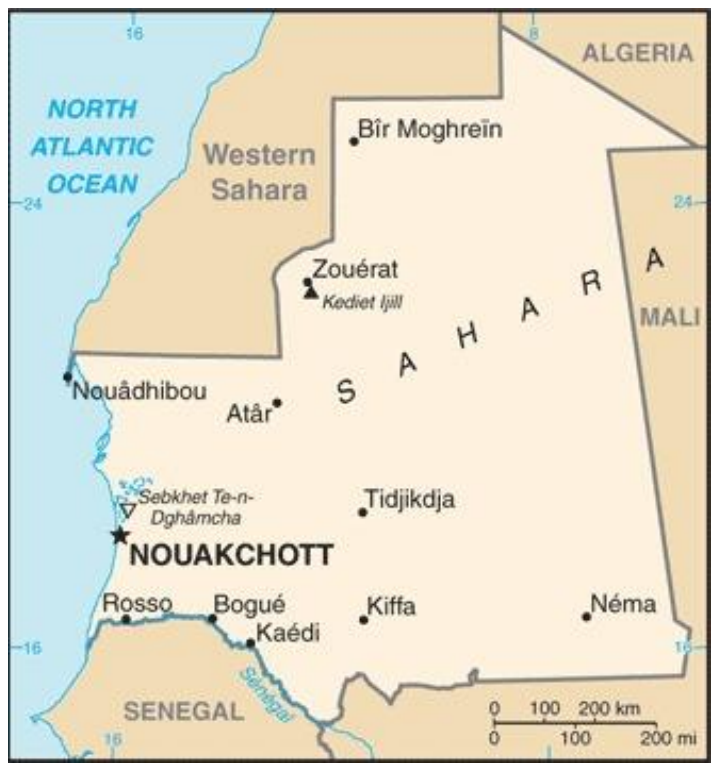

Figure 1. Political Map of Mauritania

The barren landscape has kept the population low relative to its physical size. Fewer than four million people inhabit a land of 1 million square kilometers. Population centers are few and located in coastal communities in the north, central, and southern region. History has been equally stingy to Mauritania, as marauders, invaders, and colonial slave traders all appeared on its shores at one time or another, not in search of bountiful land or resources, but to use and abuse its human labor.

Throughout nearly all of this history, slavery has had a home in this land. The practice likely had its roots among these African people who, similar to serfs in Europe, practiced human bondage as a form of trade for protection or relief from starvation. Desperate for food to survive or fearing massacre by enemies, individuals and tribes offered their own 
servitude as a means of repayment. Often those self-appointed slaves became absorbed by the tribe or society to whom they became indentured, a situation that suited both groups. (Kahn Academy, 2019.)

Beyond self-enslavement, the practice of buying and selling slaves became widespread in Mauritania with the arrival of Islam in the 8th century. It continued when Portuguese mariners arrived in 1442, followed by Dutch, and then Spanish explorers. These colonizing explorers were complicit in slave buying and trading over the following centuries, as the notorious "Atlantic slave trade" began in the late 1400's. Many of these slaves were taken to work the new sugar and tobacco plantation in the Americas and Caribbean. (Kahn Academy, 2019.) The practice continued once the many colonizers ceded power to France early in the 20th century. Regardless of the exact origin date, slavery is deeply entrenched in Mauritanian history, having been present for at least fifteen centuries.

The diversity of ethnicities in Mauritania has played a major factor on slavery's intractable hold on the country. Mauritania was named after the Mauri people, a lighter-skinned, Berber-speaking tribe traceable to the 3rd century B.C.E. (CIA Factbook, 2020.) Nearly all modern-day slaves are dark skinned, originated in sub-Saharan regions, and are commonly referred to as 'Black Moors'. Over time they have taken on many aspects of the Arab-speaking 'White Moors', Arab-Berbers who came to the land from North Africa and have been enslaving Black Moors ever since. Today Black Moors speak Hassaniya, a dialect of Arabic. In addition to Black Moors are other darker skinned people from a variety of ethnic groups, collectively referred to as Black Africans. Their ethnicities are Pulaar, Halpulaar, Fulani, Soninke, Wolof, and Bambara groups. (Rezaian, 2018.) These groups appear similar to Black Moors but have never been enslaved and differ by culture and language. The final ethnic group is the Haratines - the word literally means "freed slaves." Despite the nomenclature, Haratines normally exist along a continuum between slavery and freedom. Some belong to the former slave class of Black Moors, and most continue to suffer from race-based discrimination. (Sutton, 2012.)

White Moors almost entirely run the Mauritanian government, including the judiciary. There is little incentive for the dominant White Moors to relinquish their slave-owning practice as it serves to keep them in power and provides free labor. Efforts to eradicate slavery have been nearly impotent against a practice so deeply ingrained in the society that few people, including the slaves themselves, see it as improper. In fact, as the next section explains, many individuals born into slavery do not find fault with their situation as they know no other way of life. Put simply, they are unaware they are slaves.

\section{The Face of Modern Slavery}

As elsewhere in the world, Mauritanian slavery is not one monolithic entity; it has many faces and nuances, with slaves straddling a continuum between near freedom and complete slavery.

There are also a variety of methods used to prevent slaves from seeking freedom. Some are beaten on a regular basis, living and working in despicable conditions. Others are held with a less physical yet still angst-inducing threat of violence. Still others are kept with slave owners by mental chains, having been told since birth that their darker skin makes them less worthy that those with lighter skin. Others fear they would lose social status if they were to escape. In this poverty-stricken country, being owned by a wealthy master or a noble family endows a level of status beyond that of slaves owned by poor or middle-class masters.

Like all caste systems, this system is self-reinforcing, as slaves often believe serving their light skinned master is their role in life. Other slaves manage to escape but must live their lives in hiding, fearing repercussions. Of these, many return voluntarily, knowing no other way of life and believing they cannot survive without help. Then there is perhaps the most troubling situation of all-individuals born into slavery and entirely unaware their lives lack freedom. They do not know another way of life exists, and do not understand the overarching concept of slavery.

The face of modern slavery is continually changing as Mauritanian society's needs and demands change, and new forms of human exploitation for profit are discovered. Modern slavery looks vastly different than it did even fifty years ago. The following are the most common forms prevalent in Mauritania today. (Anti-Slavery International, 2020.)

- Human Trafficking: For purposes of prostitution, labor, criminality, marriage, or organ removal.

- Forced Labor: Any work or services where the threat or reality of punishment is used to force people to work against their will.

- Debt Bondage: A person living in poverty borrows money and is forced to work to pay off the debt.

- Descent-Based: Most common form, where people are treated as property. One's status as a slave is passed to them through their maternal side. Female slaves are sometimes raped by slave owner and their children are born and live as slaves.

- Child Slavery: This can include child trafficking, child soldiers, child marriage, and child domestic slavery. 
- Forced Early Marriage: When someone is married against their will and cannot leave. Most child marriages can be considered slavery.

Given its global reputation as a country where slavery thrives, Mauritania has become both a source and destination for men, women, and children to be used for forced labor and sex trafficking. According to the U.S. Department: "Mauritanian boy students... are trafficked within the country by religious teachers for forced begging; Mauritanian girls... are forced into domestic servitude; Mauritanian women and girls are forced into prostitution domestically or transported to countries in the Middle East for the same purpose, sometimes through forced marriages." (US State Department, 2018.)

\section{Illegal Yet Not Forbidden}

While the criminalization of slavery has had a profound impact on reducing the number of slaves in Mauritania, it remains woefully insufficient in that it has not succeeded in eliminating the practice so much as it has driven it underground. The number of individuals still enslaved in Mauritania in the year 2020 remains over 90,000, constituting over $2 \%$ of the nation's population. On the positive side that this figure is markedly lower than a decade ago when the number of slaves was approximately half a million, or $20 \%$ of the population. (Fisher, 2011.)

Today the Mauritanian government continues to deny the reality of the current situation - one which has been well documented by multiple anti-slavery non-government organizations including the oldest human rights organization in the world, Anti-Slavery International. The United Nations, the African Union, and several foreign governments concur that the practice continues to be a threat to human rights and they each continue to exert external pressure. The United States government has responded using various punitive measures that included cutting Mauritania's trade benefits in 2019 under the African Growth and Opportunity Act, or AGOA. (Kazeem, 2018.)

Having a law against slavery has not translated to justice in Mauritania, however, as bringing charges, obtaining a conviction, and applying appropriate penalties as specified by the law has been nearly impossible, and only a handful of cases have been tried as of 2020. The first successful case, in which two former slaves brought suit against their "owner" for keeping them enslaved since birth, began in 2011. After several years, the lawyer representing the two brothers could make no progress within the country. He eventually enlisted the help of two anti-slavery NGO's who took the case to a regional court. The African Committee of Experts on the Rights and Welfare of the Child were successful in challenging Mauritanian authorities, stressing the point that Mauritania failed to enforce its own anti-slavery laws. Even then, prison sentences and the fine issued to the convicted man were far, far below the recommended penalty and the case had been stalled for years awaiting Supreme Court action. The Mauritanian government was eventually forced to financially compensate the brothers.

This case continues to be an outlier, however, as the Mauritanian government efforts have been far more focused on arresting slavery protestors than slave owners. At late as 2015, eight years after slavery was abolished, not one of the 4000 child labor cases referred to the police were acted upon. Further, the law has been exceedingly ineffective as it was written such that it requires slaves, most of whom are illiterate, to file their own legal complaint. The government agency theoretically tasked with helping did not file any complaints for several years. The only support forthcoming to slaves was provided by NGO's whose funding did not originate with the government. (Rezaian, 2018.)

Given the systemic and intransigent nature of the problem, eradicating modern slavery in Mauritania is likely to remain arduous and illusive.

\section{Hidden in Plain Sight}

While the iconic image of frightened human beings being auctioned off publicly for forced labor is no longer prevalent in Mauritania, auctions do still occur elsewhere. Slave auctions were captured on film by a CNN news crew in Tripoli, Libya as recently as 2017, and CNN verified the existence of multiple locations of slave auctions occurring across Libya. (CNN, 2017.) While protests erupted globally after CNN released undercover films of those slave auctions, the situation in Mauritania, some 2900 kilometers away, is far more clandestine and far broader in scope. The world is quite unaware of this. Rather than visible auctions, slavery in Mauritania is more likely to be hidden in plain sight. The government is complicit in this crime against humanity, as its leadership continues to insist slavery no longer exists in the country.

One trick to hiding the crime is transferring Mauritania's slaves into a modern economy where they may just as easily be confused with low-income workers. Some are housemaids who pass as employees, and many live without their masters, bound by a lack of options and a belief that slavery is their fate.

Nearly all modern slaves are descendants of slaves. They live freely yet remain at their masters' beck and call. When a maid or a shepherd is needed, their presence is demanded, and the pay is non-existent. No one will admit to owning slaves, and masters are coercing and demanding their slaves to lie when approached about their status. (Voice of 
America News, 2018.)

\section{Conclusion}

Mauritania's many intractable challenges contribute to its continued reliance on slavery. Efforts to stop the practice will be most successful if multiple solutions are brought to bear. Those solutions must be implemented by an international effort as well as by Mauritania's internal efforts.

Local activists and NGO's who have been leading the anti-slavery charge for decades will continue their campaigns, but funding and support from international agencies such as the United Nations, as well as governments around the world united in their willingness to bring sanctions and limit trade with Mauritania will provide external pressure as the Mauritanian government continues its denial of the problem. Poverty and crime are at the heart of the continuing problem, and their reduction will ensure a more rapid defeat of slavery. Slavery awareness campaigns, mandatory education for all, and prosecution of all criminals buying, selling, and using slaves is key to routing out the practice.

The United States has limited - but growing - trade and investment relations with Mauritania, and a serious interest in the country's undeveloped natural gas resources. U.S. companies are actively competing for projects related to the development of this resource. Yet even this lucrative opportunity was surrendered in 2018 when Mauritania lost eligibility for trade benefits under the African Growth and Opportunity Act in 2018 due to a lack of progress combatting the lingering effects of hereditary slavery. The US, the first country to recognize Mauritania's independence, has played a strong role to encouraging a complete cessation of all slavery in all its forms. Yet other nations must not undercut the process and turn their backs on the ravages of slavery in order to fulfill their profit motives. Similarly, the US must not change course or soften its stance.

If the global community is to purge this practice that destroys human dignity, pummels human rights, and destroys quality of life, it must stand strong against all forms of oppression in their own countries as well.

\section{References}

Anti-Slavery. (2020). What is Modern Slavery? Anti-Slavery International. UK. Retrieved from https://www.antislavery.org/slavery-today/modern-slavery

CIA Factbook. Mauritania. Washington DC. Retrieved from https://www.cia.gov/library/publications/the-world-factbook/geos/mr.html

CNN. (2017). Migrants Being Sold As Slaves in Libya. https://www.youtube.com/watch?v=2S2qtGisT34

Human Rights Watch. (2020). Mauritania: Events of 2019. World Report 2020. Human Rights Watch. New York, NY. Retrieved from https://www.hrw.org/world-report/2020/country-chapters/mauritania\#ba04fe

Kazeem, Omi. Trump is Cutting Mauritania's US trade benefits because it still hasn't stopped slavery. Quartz. Africa. November 2018. Retrieved from https://qz.com/africa/1450919/trump-cuts-off-trade-with-mauritania-over-slavery/

Khan Academy. (2020). African Societies and the Beginning of the Atlantic Slave Trade. New York. Retrieved from https://www.khanacademy.org/humanities/us-history/precontact

Marlin, Rebecca \& Mathewson, Sarah. (2015). Report: Enforcing Mauritania's Anti-Slavery Legislation: the Continued Failure of the Justice System to Prevent, Protect and Punish. Anti-Slavery International, Minority Rights Group International, Society for Threatened Peoples, Unrepresented Nations and People's Organization. Retrieved from https://www.refworld.org/pdfid/561f6aa74.pdf

Max Fisher. (2011). The Country Where Slavery is Still Normal. The Atlantic. Washington, DC. Retrieved from https://www.theatlantic.com/international/archive/2011/06/the-country-where-slavery-is-still-normal/241148/

Minderoo Foundation. (2019). Modern Slavery: A Hidden, Every Day Problem. Nedlands, Western Australia. Retrieved from https://www.globalslaveryindex.org

Rezaian, Jason. (2018). Slavery is still alive in Mauritania. Can a New Court Ruling Change That? The Washington Post. Retrieved from https:/www.washingtonpost.com/news/worldviews/wp/2018/02/07/slavery-is-still-alive-in-mauritania-can-a-newcourt-ruling-help-change-that/

Sutton, John. (2012). Slavery's Last Stronghold. CNN Report. Retrieved from https://www.cnn.com/interactive/2012/03/world/mauritania.slaverys.last.stronghold/index.html

US State Department. (2018). Trafficking in Persons Report: Mauritania. Retrieved from https://www.state.gov/reports/2018-trafficking-in-persons-report/mauritania/

Voice of America. (2018). As Slavery Evolves in Mauritania, Silent Victims Prove Harder to Find. Washington, DC. 
Retrieved from https://www.voanews.com/africa/slavery-evolves-mauritania-silent-victims-prove-harder-find

\section{Copyrights}

Copyright for this article is retained by the author(s), with first publication rights granted to the journal.

This is an open-access article distributed under the terms and conditions of the Creative Commons Attribution license which permits unrestricted use, distribution, and reproduction in any medium, provided the original work is properly cited. 